\title{
ESTIMASI PENINGKATAN GENETIK Falcataria moluccana DI CIKAMPEK JAWA BARAT
}

\author{
Estimation of genetic gain of Falcataria moluccana at Cikampek, West Java \\ Mudji Susanto, Liliana Baskorowati dan/and Dedi Setiadi \\ Balai Besar Penelitian Bioteknologi Pemuliaan Tanaman Hutan \\ Jl. Palagan Tentara Pelajar Km. 15, Purwobinangun, Yogyakarta 55582 \\ Telp. 0274-895954, Faks. 0274-896080
}

Naskah masuk : 14 Mei 2013; Naskah diterima : 19 Mei 2014

\begin{abstract}
Provenance trial of Falcataria moluccuna has been established in Cikampek Experimental Forest (KHDTK). The number of families were 80 families originated from 5 provenances i.e. Biak (Papua); Wamena (Papua); Lombok; Candiroto (Central Java); and Kediri (East Java). Analyses showed that trees from Lombok had highest growth (diameter and height) at 2 and 4 years old compared to other provenances; meanwhile Biak (Papua) the provenance showed the best stem form at 4 years old. Growth and stem-form were significantly different between families in the trial at 2 and 4 years old. Estimation of individual heritability $\left(h^{2} i\right)$ were 0.03 for diameter in 2 years old and 0.08 in 4 years old; moreover $h_{i}^{2}$ were 0.12 for height in 2 years old and 0.13 in 4 years old; $h_{i}^{2}=0.27$ for stem-form in 4 years old. Estimation of genetic gain of stem-form was $14.88 \%$.
\end{abstract}

Keywords: Falcataria moluccuna, progeny test, provenance, variance component, heritability and genetic gain

\begin{abstract}
ABSTRAK
Evaluasi pertumbuhan dan bentuk batang tanaman uji keturunan Falcataria moluccuna di Kawasan Hutan Dengan Tujuan Khusus (KHDTK) Cikampek, Jawa Barat dilakukan setiap periode tertentu. Pembangunan uji keturunan ini ditujukan untuk sumber benih. Hasil data pengukuran pertumbuhan dianalisis untuk mengetahui, keragaman genetik pertumbuhan, komponen varian dan peningkatan genetik pertumbuhan maupun bentuk batang. Benih yang diuji berasal dari 80 famili dari 5 provenans yaitu: Biak (Papua); Wamena (Papua); Lombok; Candiroto (Jawa Tengah); dan Kediri (Jawa Timur). Hasil penelitian uji keturunan F. moluccuna umur 2 dan 4 tahun menunjukkan bahwa provenans dari Lombok mempunyai pertumbuhan paling tinggi (diameter dan tinggi pohon), sedangkan provenans dari Biak (Papua) mempunyai bentuk batang paling baik. Keragaman tinggi pohon dan bentuk batang dipengaruhi oleh genetik, sedangkan pengaruh genetik terhadap diameter batang sangat rendah. Estimasi nilai heritabilitas individu $\left(\mathrm{h}_{\mathrm{i}}^{2}\right)$ diameter adalah sebesar 0,03 untuk umur 2 tahun dan 0,08 untuk umur 4 tahun; sedangkan $\mathrm{h}_{\mathrm{i}}^{2}$ untuk tinggi adalah 0,12 untuk umur 2 tahun dan 0,13 untuk umur 4 tahun; serta $\mathrm{h}^{2}$ untuk bentuk batang umur 4 tahun adalah 0,27 . Estimasi peningkatan genetik bentuk batang sebesar $14,88 \%$.
\end{abstract}

Kata kunci: Falcataria moluccuna, uji keturunan, provenans, komponen varian, heritabilitas dan peningkatan genetik

\section{PENDAHULUAN}

Falcataria moluccana (Miq.) Barneby \& J.W. Grimes, sinonim dengan Paraserianthes falcataria (L.) Nielsen, Albizzia moluccana Mig., Albizia falcate Backer, dan Albizia falcataria (L.) Fosberg (Soerianegara dan Lemmens, 1993) atau lebih dikenal dengan nama sengon, dimana jenis tersebut banyak ditanam oleh masyarakat di Indonesia khususnya di pulau Jawa. Tanaman sengon banyak dikembangkan sebagai hutan rakyat karena dapat tumbuh pada kondisi iklim yang luas, serta mempunyai banyak manfaat seperti: sebagai bahan bangunan, bahan baku pulp dan kertas, papan partikel dan peti kemas. Permintaan kayu sengon selalu meningkat seiring meningkatnya kebutuhan akan kayu, sehingga berbagai cara ditempuh oleh masyarakat untuk meningkatkan produksi hutan rakyat sengon.

Hutan rakyat di Indonesia seluas 1.568.415,64 ha dan sebagian besar hutan rakyat tersebut ditanami dengan jenis Sengon (B2BPTH, 2010). 
Jumlah luasan tersebut masih terus bertambah setiap tahunnya, dikarenakan jenis ini merupakan jenis cepat tumbuh yang menggantikan kelangkaan kayu-kayu dari hutan hujan tropis sebagai bahan baku industri pulp dan kayu lapis. Kayu sengon sangat diterima di pasar dunia, selain karena ringan jenis ini juga me-rupakan hasil budi daya, bukan dari eksploitasi hutan alam. Keadaaan tersebut mendorong pe-merintah melalui Kementerian Kehutanan mem-bantu masyarakat dalam pengembangan hutan sengon ini.

Saat ini terdapat permasalahan yang dihadapi pada tanaman sengon yaitu adanya serangan karat tumor yang sangat merugikan. Akibat yang ditimbulkan dari penyakit tersebut dapat menghambat pertumbuhan sengon, bahkan mematikan tanaman. Penyakit karat tumor tersebut menurunkan produksi hutan tanaman sengon, sehingga akan mengurangi suplai kayu sengon. Upaya pengendalian penyakit karat tumor terus dilakukan melalui pencarian benih tahan terhadap penyakit karat tumor. Balai Besar Penelitian Bioteknologi dan Pemuliaan Tanaman Hutan telah memulai mengadakan pemuliaan sengon pada tahun 2008 dengan membangun uji keturunan sengon di Kediri (Jawa Timur) dan Cikampek (Jawa Barat). Uji keturunan di Cikampek dan Kediri ditujukan selain untuk meningkatkan riap volume juga untuk mendapatkan benih unggul yang tahan terhadap serangan karat tumor. Evaluasi dilakukan setiap tahun pada kedua plot uji keturunan tersebut. Plot uji keturunan di Kediri, Jawa Timur mengalami serangan penyakit karat tumor, hampir $90 \%$ individu pohon pada plot tersebut terserang penyakit sehingga plot tersebut dialihkan fungsinya menjadi plot uji resistensi; sedangkan pada plot uji keturunan sengon di Cikampek tidak ditemukan penyakit karat tumor, sehingga dilakukan penelitian produktivitas lebih lanjut.

Tujuan penelitian ini adalah untuk mengetahui besarnya pengaruh faktor ulangan, provenans, dan famili dalam provenans terhadap pertumbuhan dan bentuk batang serta parameter genetik di plot uji keturunan $F$. moluccana di Cikampek, Jawa Barat.

\section{METODOLOGI}

\section{A. Bahan}

Bahan yang digunakan dalam penelitian ini adalah pertanaman uji keturunan sengon $(F$. moluccana) di wilayah KHDTK (Kawasan Hutan dengan Tujuan Khusus) Pusat Penelitian Produktivitas Hutan, di desa Cikampek Timur, Kabupaten Karawang, Jawa Barat. Kebun benih tersebut secara geografis terletak pada $06^{\circ} 25^{\prime} 10,06^{\prime \prime}$ lintang selatan dan $107^{\circ} 27^{\prime} 50,92$ " bujur timur dengan ketinggian 57 meter dari permukaan laut. Tanaman uji keturunan tersebut ditanam pada lahan bekas tanaman Acacia mangium, Khaya anthoteca dan Himenia aurbaril dengan jenis tanah Latosol kemerahan (Hadiyan, 2010).

Kondisi lingkungan lokasi penelitian mempunyai suhu rata-rata tertinggi $31^{\circ} \mathrm{C}$ dan terendah $28^{\circ} \mathrm{C}$, dengan rata-rata curah hujan tahunan $1.111,05 \mathrm{~mm} / \mathrm{th}$; dengan rata-rata bulan kering 5,3 bulan dan bulan basah 5,3 bulan dengan iklim E menurut Schmidth Ferguson.

Uji keturunan tersebut dibangun dengan menggunakan 80 famili berasal dari 5 provenans yaitu

Tabel (Table) 1. Provenans famili-famili pada plot uji keturunan sengon di Cikampek (Provenance of families tested in SSOs of Sengon in Cikampek)

\begin{tabular}{llcccc}
\hline No. & $\begin{array}{c}\text { Provenans } \\
\text { (Provenance) }\end{array}$ & $\begin{array}{c}\text { Jumlah famili } \\
\text { (Number of } \\
\text { famili) }\end{array}$ & $\begin{array}{c}\text { Garis lintang } \\
\text { (Selatan } \\
\text { Latitute) }\end{array}$ & $\begin{array}{c}\text { Garis bujur timur } \\
\text { (Longitute) }\end{array}$ & $\begin{array}{c}\text { Ketinggian tempat } \\
\text { (m dpl) } \\
\text { (Altitude) }(m \text { asl) }\end{array}$ \\
\hline 1. & Candiroto & 24 & ${ }^{0} 15^{\prime}$ & $110^{0} 09^{\prime}$ & 500 \\
2. & Biak Papua & 19 & $1^{0} 1^{\prime}$ & $123^{0} 47^{\prime}$ & 70 \\
3. & Wamena & 11 & $4^{0} 1^{\prime}$ & $139^{0} 10^{\prime}$ & 1.700 \\
4. & Lombok & 17 & $08^{0} 18^{\prime}-08^{0} 32^{\prime}$ & $116^{0} 07^{\prime}-116^{0} 23^{\prime}$ & $101-665$ \\
5. & Kediri & 9 & $07^{0} 48^{\prime}-07^{0} 56^{\prime}$ & $112^{0} 11^{\prime}-112^{0} 15^{\prime}$ & $121-618$ \\
\hline & Jumlah & 80 & & & \\
\hline
\end{tabular}


ras lahan Candiroto (Temanggung Jawa Tengah), Biak (Papua), Wamena (Papua), Lombok (NTB) dan ras lahan Kediri (Jawa Timur). Informasi mengenai materi (seedlot maupun famili) yang digunakan disajikan pada Tabel 1. Plot uji keturunan tersebut dibangun berbentuk desain baris kolom dengan 6 ulangan dan blok tak lengkap. Jumlah pohon setiap plot adalah 4 pohon dengan model linier (baris) dan jarak tanam 3 meter antar baris dan 2 meter antar pohon di dalam baris.

\section{B. Metode}

\section{Pengukuran karakter}

Pengukuran tinggi pohon dan diameter batang dilakukan pada umur 2 dan 4 tahun, sedangkan pengukuran skor bentuk batang dilakukan mulai umur 4 tahun. Tinggi pohon yang diukur adalah tinggi pohon total yaitu mulai dari permukaan tanah sampai dengan tajuk paling atas. Diameter batang yang diukur adalah diameter batang pada ketinggian diameter setinggi dada $(1,3 \mathrm{~m})$. Satuan yang digunakan untuk tinggi pohon adalah meter $(\mathrm{m})$ dan satuan untuk diameter batang adalah centimeter $(\mathrm{cm})$. Skor bentuk batang menggunakan skor 1 sampai dengan skor 4 dengan ketentuan seperti Tabel 2 sebagai berikut (skore dimodifikasi dari Pinyopusarerk et al., 2004; MacDonald etal., 2014).

\section{Analisis statistik}

Data yang dianalisis adalah data dari 6 ulangan. Analisis statistik menggunakan paket software Genstat Versi 5.3.2. (Payene et al., 1987). Estimasi komponen-komponen varian dihitung dengan menggunakan kuadrat tengah dari hasil analisis varian (ANOVA). Model analisis varian yang digunakan adalah sebagai berikut :

$$
\mathrm{Y}_{i j k}=\mu+\mathrm{B}_{i}+\mathrm{P}_{j}+\mathrm{F}_{k(j)}+\left(\mathrm{B}_{i}^{*} \mathrm{~F}_{k(j)}\right)+\mathrm{e}_{i j k}
$$

Keterangan:

$\mathrm{Y}_{i j k}=$ pengamatan individu ulangan ke i, provenans ke $\mathrm{j}$, family ke $\mathrm{k}$ di dalam provenans ke $\mathrm{j}$, interaksi ulangan ke i dengan famili ke j (individual observation of the $i^{\text {th }}$ replicate of the $j^{\text {th }}$ provenance of the $k^{\text {th }}$ family within the $j^{\text {th }}$ provenance of the interaction between the $i$ th repli cate and the $k^{\text {th }}$ family within the $j$ th provenance)

$\mu=$ rerata umum (overall mean)

$\mathrm{B}_{i}=$ pengaruh ulangan ke $\mathrm{i}$ (effect of the $i^{\text {th }}$ replicate)

$\mathrm{P}_{j}=$ pengaruh provenans ke $\mathrm{j}$ (effect of the $j^{\text {th }}$ provenance)

$\mathrm{F}_{k(j)}=$ pengaruh famili ke $\mathrm{k}$ dalam provenans ke $\mathrm{j}$ (effect of the $k^{\text {th }}$ family which is nested within thejth provenance)

$\mathrm{e}_{i j k}=\operatorname{sisa}$ (residual error with a mean of zero)

Tabel (Table) 2. Penentuan skor untuk penilaian bentuk batang tanaman sengon (F. moluccana) (Scoring levels for stem form assessment of sengon (F. moluccana))

\begin{tabular}{|c|c|c|c|}
\hline No. & $\begin{array}{l}\text { Skor } \\
\text { Score }\end{array}$ & $\begin{array}{c}\text { Gambar } \\
\text { Picture }\end{array}$ & $\begin{array}{c}\text { Keterangan } \\
\text { Note }\end{array}$ \\
\hline 1. & 4 & & Lurus (Straight) \\
\hline 2. & 3 & & Defect \\
\hline 3. & 2 & & sangat defect \\
\hline 4. & 1 & & sympodial/forking \\
\hline
\end{tabular}


Perhitungan komponen varian diperoleh dengan menggunakan analisis model campuran. Ulangan dan provenans sebagai pengaruh pasti (fixed effect) famili dalam provenans dan interaksi famili dalam provenans dengan ulangan sebagai pengaruh random (random effect) berdasar REML (Restricted Maximum Likelihood).

\section{Analisis parameter genetik}

a. Heritabilitas individu

Komponen varians famili dalam provenans digunakan untuk mengestimasi nilai heritabilitas individu $\left(\mathrm{h}_{\mathrm{i}}^{2}\right)$ dengan rumus menurut Williams \& Matheson (1994):

$$
\mathrm{h}_{\mathrm{i}}^{2}=1 / \mathrm{r} * \sigma_{\mathrm{f}}^{2} / \sigma_{\mathrm{p}}^{2}
$$

Keterangan:

$$
\begin{aligned}
& \mathrm{r}=\text { koefisien kekerabatan (coefficient of } \\
& \text { relationship) } \\
& \sigma_{\mathrm{f}}^{2}=\text { komponen varians di antara famili di dalam } \\
& =\left(\sigma^{2} f^{+} \sigma^{2}{ }_{b} * f^{+} \sigma^{2}{ }_{e}\right) \\
& \sigma_{b^{* f}}^{2} \quad \text { komponen varian interaksiulangan dan family }
\end{aligned}
$$

Koefisien kekerabatan (r) untuk untuk menghitung heritabilitas individu diasumsikan sebesar 1/4 -untuk famili-famili half-sib (Falconer \& Mackay, 1996).

b. Korelasi genetik dan korelasi fenotipik antar sifat

Korelasi genetik $\left(\mathrm{r}_{\mathrm{g}}\right)$ dan korelasi fenotipik $(\mathrm{r})$ dihitung menurut metodologi dari Williams and Matheson (1994) yang didasarkan rumus sebagai berikut:

$$
r_{g}=\frac{\operatorname{Cov}_{f}(X Y)}{\left[\sigma_{f}^{2}(x) \cdot \sigma_{f}^{2}(y)\right]^{1 / 2}}
$$

Keterangan :

$$
\begin{aligned}
\operatorname{Cov}_{\mathrm{f}}(\mathrm{XY})= & \text { Kovarian dua sifat }(\mathrm{x} \text { dan } \mathrm{y}) \text { pada level } \\
& \text { famili }(\text { covariance of the two traits at } \\
& \text { thefamily level }) \\
\sigma_{\mathrm{f}}^{2}(\mathrm{x})= & \text { varian sifat }(\mathrm{x}) \text { pada level famili } \\
& (\text { family }- \text { level variance components of } \\
& \text { trait }(\mathrm{x})) \\
= & \text { varian sifat }(\mathrm{y}) \text { pada level famili } \\
& (\text { family-level variance components of } \\
& \text { trait }(y))
\end{aligned}
$$

Korelasi fenotipik $\left(r_{p}\right)$ dihitung sebagai berikut :

$$
r_{p}=\frac{\operatorname{Cov}_{p}(X Y)}{\left[\sigma_{p}^{2}(x) \cdot \sigma_{p}^{2}(y)\right]^{1 / 2}}
$$

Keterangan :

$\mathrm{Cov}_{p}(\mathrm{XY})=$ Kovarian dua sifat (x dan y) pada level fenotipik (covariance of the two traits at the phenotypic level)

$\sigma_{\mathrm{p}}^{2}(\mathrm{x})=$ varian sifat $(\mathrm{x})$ pada level fenotipik (phenotypic-level variance components of trait $(x))$

$\sigma_{\mathrm{p}}^{2}(\mathrm{y})=$ varian sifat $(\mathrm{y})$ pada level fenotipik (phenotypic-level variance components of trait (y))

c. Korelasi genetik sesama sifat antar umur

Korelasi genetik $\left(\mathrm{r}_{\mathrm{g}}\right)$ dihitung sesama sifat antar didasarkan rumus menurut Williams et al. (2002):

$$
r_{g}=\frac{\operatorname{Cov}_{f}(x 1, x 2)}{\left[\sigma_{f}^{2}(x 1) \cdot \sigma_{f}^{2}(x 2)\right]^{1 / 2}}
$$

Keterangan :

$\operatorname{Cov}_{\mathrm{f}}(\mathrm{x} 1, \mathrm{x} 2)=$ Kovarian sesama sifat $(\mathrm{x} 1$ dan $\mathrm{x} 2)$ pada level famili (covariance of The same traits (x1 and $x 2)$ at the family level)

$\sigma 2 \mathrm{f}(\mathrm{x})=$ varian sifat $(\mathrm{x} 1)$ pada level famili (family-level variance components of trait (x1))

$\sigma 2 \mathrm{f}(\mathrm{y}) \quad=$ varian sifat $(\mathrm{x} 2)$ pada level famili (family-level variance components of trait (x2))

$\mathrm{x} 1$

$=$ sifat X pd umur 2 tahun (on 2 years old)

$\mathrm{x} 2$

$=$ sifat $\mathrm{X}$ pd umur 4 tahun (on 4 years old)

\section{d. Perolehan genetik}

Perolehan genetik $(\Delta \mathrm{G})$ dari seleksi di uji keturunan di prediksi dengan formula menurut Shelbourne(1992):

$$
\Delta \mathrm{G}=\mathrm{h}_{\mathrm{i}}^{2} \cdot \mathrm{i} \cdot \sigma_{\mathrm{p}}
$$

Keterangan :

$\mathrm{i}=$ intensitas seleksi (selection intensity)

$\sigma_{\mathrm{p}}=$ standard deviasi fenotip dari suatu sifat (the phenotypic standard deviation for the trait of interest)

$\mathrm{h}_{\mathrm{i}}^{2}=$ heritabilitas individu dari suatu sifat (indivi_dual treeheritability for the traitof interest). 


\section{HASIL DAN PEMBAHASAN}

\section{A. Hasil}

\section{Keragaman pertumbuhan}

Hasil analisis pengukuran karakter pertumbuhan (tinggi dan diameter) uji keturunan sengon disajikan pada Tabel 3. Analisis varian dari karakter tinggi, diameter dan bentuk batang disajikan pada Tabel 4.

\section{Komponen varian}

Estimasi nilai komponen varian untuk sifat tinggi, diameter, dan bentuk batang serta prosen- tase nilai varian terhadap varian total disajikan pada Tabel 5 .

\section{Estimasi korelasi genetik, heritabilitas individu dan peningkatan genetik \\ Hasil perhitungan estimasi nilai heritabilitas individu diameter dan tinggi pohon umur 2 dan 4 tahun serta bentuk batang umur 4 tahun dan estimasi korelasi fenotipik dan genetik antar sifat umur 4 tahun disajikan pada Tabel 6 serta table 7. Hasil perhitungan estimasi peningkatan genetik disajikan pada Tabel 8 .}

Tabel(Table) 3. Rata-rata pertumbuhan (tinggi dan diameter) pohon uji keturunan sengon di Cikampek (The mean of growth (height and diameter) of sengon seed orchard at Cikampek)

\begin{tabular}{lllllll}
\hline & & \multicolumn{2}{c}{$\begin{array}{c}\text { Tinggi }(\mathrm{m}) \\
(\text { Heigh })(\mathrm{m})\end{array}$} & \multicolumn{2}{c}{$\begin{array}{c}\text { Diameter batang }(\mathrm{cm}) \\
(\mathrm{Dbh})(\mathrm{cm})\end{array}$} & $\begin{array}{l}\text { Bentuk batang } \\
\text { pada umur } 4 \text { th } \\
\text { (Stemform in 4 }\end{array}$ \\
\cline { 3 - 6 } No. & $\begin{array}{l}\text { Provenans } \\
\text { (Provenance) }\end{array}$ & $\begin{array}{l}\text { Umur } \\
2 \text { tahun } \\
\text { (2 years old })\end{array}$ & $\begin{array}{l}\text { Umur } \\
4 \text { tahun } \\
\text { (4 years old })\end{array}$ & $\begin{array}{l}\text { Umur } \\
\text { 2 tahun } \\
\text { (2 years old })\end{array}$ & $\begin{array}{l}\text { Umur } \\
4 \text { tahun } \\
\text { (4 years old })\end{array}$ & years old) \\
\hline 1 & Candiroto & 6,09 & 11,75 & 6,73 & 10,00 & 2,05 \\
2 & Biak Papua & 5,84 & 11,55 & 6,62 & 9,77 & 2,11 \\
3 & Wamena & 5,08 & 11,24 & 5,79 & 9,77 & 2,02 \\
4 & Lombok & $\mathbf{6 , 4 7}$ & $\mathbf{1 2 , 2 5}$ & $\mathbf{7 , 6 8}$ & $\mathbf{1 0 , 4 6}$ & 1,97 \\
5 & Kediri & 5,65 & 11,27 & 6,30 & 11,27 & 1,97 \\
\hline & Rata-rata & 5,97 & 11,70 & 6,65 & 9,93 & 2,03 \\
\hline
\end{tabular}

Tabel(Table) 4. Analisis varian tinggi, diameter dan bentuk batang uji keturunan sengon di Cikampek, Jawa Barat (Variance analysis of height, diameter and stem form of sengon seed orchard at Cikampek West Jawa)

\begin{tabular}{|c|c|c|c|}
\hline $\begin{array}{l}\text { Sumber variasi } \\
\text { (Source of variation) }\end{array}$ & & $\begin{array}{l}\text { adrat tengah } \\
\text { ean square) }\end{array}$ & \\
\hline $\begin{array}{l}\text { Umur } 2 \text { tahun } \\
\text { (2 years old })\end{array}$ & $\begin{array}{l}\mathrm{db} \\
(d f)\end{array}$ & $\begin{array}{l}\text { Tinggi } \\
\text { Height }\end{array}$ & $\begin{array}{l}\text { Diameter } \\
(d b h)\end{array}$ \\
\hline Ulangan (replication) & 5 & $28,18^{(* * *}$ & $35,00^{(* * *}$ \\
\hline Provenans (provenance) & 4 & $42,26^{(* * *}$ & $32,980^{(* * *}$ \\
\hline $\begin{array}{l}\text { Famili (Provenans) } \\
{[\text { family (provenance)] }}\end{array}$ & 75 & $4,73^{(* * *}$ & $6,440^{(* * *}$ \\
\hline $\begin{array}{l}\text { Ulangan*Famili (provenans) } \\
\text { [replication*family (provenance)] }\end{array}$ & 358 & $5,61^{(* * *}$ & $7,130^{(* * *}$ \\
\hline Error & 751 & 1,67 & 2,89 \\
\hline
\end{tabular}


Tabel (Table) 4. Lanjutan (Continued)

\begin{tabular}{|c|c|c|c|c|}
\hline $\begin{array}{l}\text { Umur } 4 \text { tahun } \\
\text { (4 years old) }\end{array}$ & $\begin{array}{l}\mathrm{db} \\
(d f)\end{array}$ & $\begin{array}{l}\text { Tinggi } \\
\text { (height) }\end{array}$ & $\begin{array}{l}\text { Diameter } \\
(d b h)\end{array}$ & $\begin{array}{l}\text { Bentuk } \\
\text { Batang (Stem- } \\
\text { form) }\end{array}$ \\
\hline Ulangan (replication) & 5 & $101,92^{(* * *}$ & $74,35^{(* * *}$ & $1,93^{* *}$ \\
\hline Provenans (provenance) & 4 & $24,53^{(* * *}$ & $19,45^{(*}$ & $1,19^{\mathrm{ns}}$ \\
\hline $\begin{array}{l}\text { Famili (Provenans) } \\
{[\text { family (provenance)] }}\end{array}$ & 75 & $12,38^{(* * *}$ & $14,99^{(* * *}$ & $1,17^{(* *}$ \\
\hline $\begin{array}{l}\text { Ulangan*Famili (provenans) } \\
\text { [replication*family (provenance)] }\end{array}$ & 319 & $9,57^{(* * *}$ & $11,85^{(* * *}$ & $0,89^{(* *}$ \\
\hline Error & 637 & 3,83 & 6,30 & 0,66 \\
\hline
\end{tabular}

\section{Keterangan :}

$\mathrm{db}:$ Derajat bebas $(d f=$ Degree offreedom $)$

ns : Tidak signifikan (Not significantly different)

$* * *$ : Signifikan pada taraf uji $\mathrm{P}>0,001$ (Significant at the level $>0.001$ )

** : Signifikan pada taraf uji $0,01<\mathrm{P}<0,001$ (Significant at the level $0.01<P<0.001$ )

* : Signifikan pada taraf uji $0,05<\mathrm{P}<0,01$ (Significant at the level $0.05<P<0.01$ )

Tabel (Table) 5. Estimasi komponen varian tinggi, diameter dan bentuk batang uji keturunan sengonumur 4 tahun di Cikampek, Jawa Barat (Estimation of component variance of height, diameter and stem form of 4 years old sengon seedling seed orchard at Cikampek, West Java)

\begin{tabular}{lcccccccc}
\hline \multicolumn{1}{c}{$\begin{array}{c}\text { Sifat } \\
(\text { Traits })\end{array}$} & $\begin{array}{c}\sigma^{2} \text { ulangan } \\
\left(\sigma^{2} \text { replication }\right)\end{array}$ & $\begin{array}{c}\sigma^{2} \text { ulangan } \\
\left(\sigma^{2} \text { replication }\right) \\
(\%)\end{array}$ & $\sigma^{2} \mathrm{f}$ & $\sigma^{2} \mathrm{f}(\%)$ & $\begin{array}{c}\sigma^{2} \text { famili*ulangan } \\
\left(\sigma^{2} \text { family*replication }\right)\end{array}$ & $\begin{array}{c}\sigma^{2} \text { famili*ulangan } \\
\left(\sigma^{2} \text { family }{ }^{*} \text { replication }\right) \\
(\%)\end{array}$ & $\sigma^{2} \mathrm{e}$ & $\sigma^{2} \mathrm{e}(\%)$ \\
\hline $\begin{array}{l}\text { Tinggi pohon } \\
(\text { height })\end{array}$ & 0,620 & 8,63 & 0,394 & 5,48 & 2,301 & 32,06 & 3,862 & 53,82 \\
$\begin{array}{l}\text { Diameter } \\
(\text { dbh })\end{array}$ & 0,469 & 5,01 & 0,321 & 3,43 & 2,255 & 24,08 & 6,320 & 67,49 \\
$\begin{array}{l}\text { Bentuk } \\
\begin{array}{l}\text { Batang } \\
(\text { Stem-form })\end{array}\end{array}$ & 0,010 & 1,27 & 0,014 & 1,78 & 0,069 & 8,94 & 0,682 & 88,01 \\
\hline
\end{tabular}

Keterangan (Remarks):

$\sigma_{\mathrm{f}}^{2}=$ Varian famili (Variance component of family)

$\sigma_{\mathrm{e}}^{2}=$ Varian error (Variance component of error)

Tabel (Table) 6. Estimasi heritabilitas individu $\left(\mathrm{h}_{\mathrm{i}}^{2}\right)$, korelasi fenotipik $\left(\mathrm{r}_{\mathrm{p}}\right)$ dan korelasi genetik $\left(\mathrm{r}_{\mathrm{g}}\right)$ antar sifat pada uji keturunan sengon di Cikampek (Estimation of individual heritability individu $\left(h_{i}^{2}\right)$, fenotypic $\left(r_{p}\right)$ and genetic correlation between characters of sengon seed orchard Cikampek)

\begin{tabular}{lccccc}
\hline & $\begin{array}{c}\text { Korelasi fenotipik dan korelasi genetik padaumur 4 tahun } \\
\text { (Phenotypic and genotypic correlation on 4 years old })\end{array}$ & $\begin{array}{c}\text { Heritabilitas individu }\left(\mathrm{h}^{2}\right) \\
\text { (Individual heritability) }\end{array}$ \\
\hline $\begin{array}{l}\mathrm{r}_{\mathrm{g}} \\
\mathrm{r}_{\mathrm{p}}\end{array}$ & $\begin{array}{c}\text { Diameter } \\
(\mathrm{dbh})\end{array}$ & $\begin{array}{c}\text { Tinggi pohon } \\
(\text { height })\end{array}$ & $\begin{array}{c}\text { Bentuk } \\
\text { batang } \\
(\text { Stem-form })\end{array}$ & $\begin{array}{c}\text { Umur } 2 \\
\text { tahun } \\
(2 \text { years old })\end{array}$ & $\begin{array}{c}\text { Umur } 4 \text { tahun } \\
\text { (4 years old })\end{array}$ \\
\hline Diameter $(\mathrm{dbh})$ & - & 0,91 & 0,04 & 0,03 & 0,08 \\
\hline Tinggi pohon $($ height $)$ & 0,74 & - & $-0,48$ & 0,12 & 0,13 \\
\hline $\begin{array}{l}\text { Bentuk batang }(\text { Stem- } \\
\text { form })\end{array}$ & 0,05 & 0,06 & - & - & 0,27 \\
\hline
\end{tabular}

Keterangan (Remarks) : Korelasi genetik $\left(\mathrm{r}_{\mathrm{g}}\right)$ berada di atas diagonal; Korelasi fenotipik $\left(\mathrm{r}_{\mathrm{p}}\right)$ berada di bawah diagonal(Genetic correlation is abovethe diagonal; phonotypic correlation is under the diagonal) 
Tabel (Table) 7. Korelasi genetik $\left(\mathrm{r}_{\mathrm{g}}\right)$ antar sifat yang sama pada umur yang berbeda pada uji keturunan sengon di Cikampek (Genetic correlation between same trait in different age of sengon seed orchard Cikampek)

\begin{tabular}{lcc}
\hline \multicolumn{1}{c}{$\begin{array}{c}\text { Sifat } \\
(\text { Trait })\end{array}$} & $\begin{array}{c}\text { Diameter pada umur } \\
4 \text { tahun } \\
(\text { dbh in 4 years old })\end{array}$ & $\begin{array}{c}\text { Tinggi pohon pada umur } \\
4 \text { tahun } \\
\text { (height in 2 years old })\end{array}$ \\
\hline $\begin{array}{l}\text { Diameter pada umur 2 tahun } \\
\text { (dbh in 2 years old })\end{array}$ & 0,16 & \\
$\begin{array}{l}\text { Tinggi pohon pada umur 2 tahun } \\
\text { (height in 2 years old })\end{array}$ & & 0,93 \\
\hline
\end{tabular}

Tabel(Table) 8. Estimasi peningkatan genetik pertumbuhan pada uji keturunan sengon umur 4 tahun di Cikampek (Estimation of genetic gain of growth 4 years old sengon at Cikampek seed orchard)

\begin{tabular}{lcccccc}
\hline \multicolumn{1}{c}{$\begin{array}{c}\text { Sifat } \\
\text { (Traits) }\end{array}$} & $\begin{array}{c}\text { Rata-rata } \\
\text { (Mean) }\end{array}$ & $\sigma_{\mathrm{p}}$ & $\mathrm{i}$ & $\mathrm{h}^{2}{ }_{\mathrm{i}}$ & $\Delta \mathrm{G}$ satuan & $\Delta \mathrm{G} \%$ \\
\hline Diameter $($ dbh) & $9,93 \mathrm{~cm}$ & 3,06 & 1,271 & 0,08 & 0,03 & 3,13 \\
Tinggi pohon $($ heigh $)$ & $11,70 \mathrm{~m}$ & 2,68 & 1,271 & 0,13 & 0,04 & 3,78 \\
Bentuk batang & 2,03 & 0,88 & 1,271 & 0,27 & 0.15 & 14,88 \\
(Stem form) & & & & & & \\
\hline
\end{tabular}

\section{B. Pembahasan}

\section{Keragaman pertumbuhan}

Rerata pertumbuhan umur 2 dan 4 tahun pada Tabel 3 menunjukkan bahwa tanaman sengon yang berasal dari Lombok mempunyai rerata pertumbuhan paling cepat dibandingkan tanaman sengon dari provenans lainnya. Sedangkan tanaman sengon yang berasal dari Wamena mempunyai pertumbuhan paling lambat pada umur yang sama dibandingkan tanaman sengon yang berasal dari provenans uji lainnya.

Hasil anova yang disajikan pada Tabel 4, menunjukkan adanya keragaman pertumbuhan diantara ulangan untuk karakter tinggi pohon dan diameter batang pada umur 2 tahun maupun 4 tahun, serta keragaman bentuk batang tanaman uji pada umur 4 tahun. Keragaman ketiga karakter yang diamati pada setiap ulangan (blok) tersebut, disebabkan oleh perbedaan lingkungan tempat tumbuh pada masing-masing ulangan. Perbedaan-perbedaan tersebut diperlihatkan antara lain: oleh tumbuhan bawah yang berbeda; kemiringan masing-masing ulangan berbedabeda.
Keragaman yang tinggi juga terjadi pada level provenans dan level famili di dalam provenans untuk tinggi pohon dan diameter batang. Keragaman yang tinggi pada ketiga karakter (tinggi pohon, diameter batang dan bentuk batang) diantara famili di dalam provenans mengindikasikan bahwa diantara famili mempunyai keragaman genetik yang tinggi untuk ketiga karakter tersebut. Keragaman yang tinggi diantara famili pada uji keturunan $F$. moluccana di Cikampek tersebut sangat menguntungkan pada program pemuliaan yang mengandalkan seleksi. Keragaman yang tinggi pada karakter tinggi pohon dan diameter batang antar famili juga dilaporkan oleh Hadiyan (2008) di uji keturunan F. moluccana di Cikampek pada umur 6 bulan dan 1 tahun. Selain itu terdapat keragaman yang tinggi pada diameter batang dan tinggi pohon diantara famili n pada uji keturunan sengon yang menguji 110 famili di Candiroto, Jawa Tengah, pada umur 4 bulan dan 3 tahun (Susanto, 1997; 1999). Sementara Ismail dan Hadiyan (2008) melaporkan pada umur 8 bulan di uji keturunan F. moluccana di Kediri terdapat keragaman yang 
tinggi antar famili untuk karakter diameter batang namun tidak ada keragaman antar famili untuk karakter tinggi tanaman. Dwiyanti (2009) melaporkan hasil penelitian di plot uji jenis di Cirangsad, Bogor, pada umur 2 tahun dengan 9 famili sengon dari Solomon menunjukkan tidak ada keragaman tinggi pohon dan diameter batang diantara famili. Mukmin (2004) melaporkan hasil penelitian di uji keturunan Sengon di Taman Hutan Blok Cikabayan, IPB, yang menguji 18 famili dari Banjarnegara, Wonosobo dan Lumajang bahwa pada umur 1 dan 3 bulan tinggi pohon berbeda nyata antar famili, tetapi pada umur 6 bulan tinggi pohon tidak menunjukkan berbeda nyata antar famili. Charomaini (1996) melaporkan hasil penelitian di uji keturunan sengon umur 2 tahun di Sumberjaya, Lampung Barat, yang menguji 10 famili yg berasal dari Pare bahwa diameter batang dan tinggi pohon tidak menunjukkan berbeda nyata antar famili. Hasil analisis isozyme oleh Siregar et al. (2002) pada semai sengon yang berasal dari 27 famili dari 6 populasi di Jawa Barat 1 menunjukkan adanya variasi genetik. Ishiguri et al. (2008) telah meneliti sengon di Serpong Botanical Garden Indonesia dengan hasil bahwa sengon mempunyai variasi pertumbuhan dan sifat-sifat kayu. Olivia \& Siregar (2012) menyatakan bahwa hasil analisis DNA Sengon di Jawa menunjukkan adanya nilai keragaman genetik yang cukup tinggi. Penelitian lain adanya keragaman antar provenans pada tinggi pohon dan diameter batang merbau diteliti oleh Yudohartono \& Ismail (2012); keragaman diameter batang Acacia mangium antar provenans maupun antar famili di dalam provenans diteliti oleh Susanto et al. (2012) pada umur 2 bulan dan Susanto et al. (2013) pada umur 5 tahun; keragaman diameter dan tinggi batang antar provenans pada Araucaria cunninghamii umur 1 tahun dan 2 tahun Setiadi et al. (2009); dan keragaman tinggi pohon dan diameter batang antar provenans maupun antar famili di dalam provenans pada $A$. cunninghamii umur 5 tahun di jawa Timur oleh Setadi dan Susanto (2012).

\section{Komponen varian}

Dari hasil analisis komponen dapat diketahui bahwa varian sisa (error) berkisar antara 53,82\% sampai dengan $88,01 \%$ terhadap total varian (Tabel 5). Varian sisa tersebut merupakan varian yang disebabkan oleh perbedaan plot dan perbedaan individu pohon di dalam plot. Varian in- teraksi famili dengan ulangan untuk tinggi pohon sebesar $32,06 \%$ dan untuk diameter $24,08 \%$ sedangkan untuk interaksi famili sebesar 8,94\%. Varian famili besarnya $1,78 \%$ sampai dengan $5,48 \%$. Varian famili tersebut lebih rendah bila dibandingkan dengan komponen varian lainnya. Hal tersebut mengindikasikan bahwa pengaruh pohon induk terhadap tinggi pohon, diameter batang dan bentuk batang cukup rendah.

\section{Estimasi korelasi genetik, heritabilitas individu dan peningkatan genetik}

Tabel 6 memperlihatkan korelasi genetik dan fenotipik antar sifat pada uji keturunan sengon di Cikampek. Diameter batang dan tinggi pohon mempunyai korelasi yang positif kuat baik pada korelasi fenotipik maupun genetik. Pada penelitian ini korelasi fenotipik antara tinggi pohon dan diameter batang sebesar $r_{p}=0,74$. Korelasi fenotipik antara tinggi pohon dan diameter batang Sengon tersebut juga ditemukan oleh Krisnawati et al. (2011) yaitu sebesar $r_{p}=0,79$. Penelitian yang dilakukan oleh Broto (2008) pada hutan rakyat Sengon di Banjar, Jawa Barat menunjukkan bahwa korelasi fenotipik antara diameter batang dengan tinggi pohon sebesar $r_{p}=0,802$.

Bentuk batang dan diameter mempunyai korelasi yang sangat lemah atau dapat dikatakan tidak terdapat korelasi baik korelasi fenotipik maupun genetik. Korelasi genetik antara bentuk batang dan tinggi pohon terlihat negatif namun tidak terdapat korelasi fenotipik. Heritabiltas individu pada diameter batang terlihat sangat kecil sedangkan heritabilitas tinggi pohon dan bentuk batang tergolong sedang.

Berdasarkan hasil analisis korelasi genetik antar umur pada Tabel 7. menunjukkan bahwa antara tinggi pohon umur 2 tahun dengan tinggi pohon umur 4 tahun mempunyai korelasi genetik yang sangat kuatyaitu sebesar $\mathrm{r}_{\mathrm{g}}=0,93$, sedangkan diameter batang umur 2 tahun dan diameter batang 4 tahun mempunyai korelasi genetik yang lemah yaitu sebesar $r_{g}=0,16$. Hadiyan (2008) melaporkan hasil analisis korelasi genetik dan nilai heritabilitas individu di uji keturunan sengon di Cikampek pada umur 6 bulan dan 1 tahun bahwa korelasi genetik antar umur untuk tinggi pohon dan diameter batang sangat lemah yaitu $r_{g}=-0,04$ untuk tinggi pohon dan $r_{\mathrm{g}}=-0,05$ untuk diameter batang, serta heritabilitas individu untuk tinggi pohon sebesarh $\mathrm{h}_{\mathrm{i}}^{2}=0,10$ danuntuk diameter sebesar $\mathrm{h}_{\mathrm{i}}^{2}=0,07$. 
Nilai heritabilitas individu diameter tergolong rendah yaitu $\mathrm{h}_{\mathrm{i}}^{2}=0,03$ pada umur 2 tahun dan $\mathrm{h}_{\mathrm{i}}^{2}=0,08$ pada umur 4 tahun. Nilai heritabilitas individu yang rendah juga ditemukan pada uji keturunan Acacia mangium pada umur 3 tahun yaitu sebesar $\mathrm{h}_{\mathrm{i}}^{2}=0,08$ yang disajikan oleh Hai (2009). Penelitian lain tentang nilai heritabilitas individu diameter batang yang rendah juga ditemukan pada Jati umur 5,5 tahun yaitu sebesar $\mathrm{h}_{\mathrm{i}}^{2}=0,05$ (Muslimin et al., 2013); nilai heritabilitas individu diameter pada F. molucanna di Kediri yaitu $\mathrm{h}_{\mathrm{i}}^{2}=0,02$ (Baskorowati et al., 2012); dan nilai heritabilitas individu diameter pada $A$. cunninghamii umur 1 sebesar $^{2}{ }_{\mathrm{i}}=0,06$ dan umur 2 tahun sebesar $\mathrm{h}_{\mathrm{i}}^{2}=0,07$ (Setiadi et al., 2009).

Nilai heritabilitas individu tinggi pohon sebesar $\mathrm{h}_{\mathrm{i}}^{2}=0,13$ dan nilai heritabilitas individu bentuk batang sebesar $\mathrm{h}_{\mathrm{i}}^{2}=0,27$. Hal tersebut mengindikasikan bahwa besarnya varian aditif tinggi batang sebesar $13 \%$ dari nilai total varian, dan besarnya varian aditif bentuk batang sebesar $27 \%$ dari nilai total varian. Sehingga dapat dikatakan bahwa keragaman tinggi pohon dan bentuk batang dikendalikan oleh faktor genetik (apakah nilai varian sebesar itu sudah menyatakan bahwa kendali faktor genetik tinggi, jelaskan). Berdasarkan hasil tersebut maka seleksi pohon yang akan dilakukan cukup menggunakan tinggi pohon dan bentuk batang. Tinggi pohon dan diameter mempunyai korelasi genetik positip yang kuat artinya jika akan meningkatkan tinggi pohon maka diameter batang juga akan meningkat. Namun bentuk batang dan tinggi pohon mempunyai korelasi genetik yang negatif, jika akan memilih bentuk batang yang baik maka tidak akan memperbaiki sifat tinggi pohon. Dengan mempertimbangkan hasil tersebut maka diperlukan streategi yang tepat jika akan melakukan seleksi pohon berdasarkan karakter tinggi dan bentuk batang. Uji keturunan tersebut dapat dilakukan seleksi pohon setelah umur 2 tahun, karena setelah umur 2 tahun sudah memperlihatkan pertumbuhan yang stabil, hal tersebut dengan diperlihatkan dengan korelasi genetik antarumur 2 tahun dan 4 tahun untuk tinggi pohon yang positif dan sangat kuat (Tabel 7).

Tabel 8 menunjukkan bahwa apabila uji keturunan dilakukan seleksi pohon secara seleksi massa dengan meninggalkan 50\% pohon terbaik, maka peningkatan genetik diameter batang sebesar 3,13\%, tinggi pohon sebesar 3,78 \% dan bentuk batang sebesar $14,88 \%$. Peningkatan ge- netik diameter batang dan tinggi pohon tersebut tergolong kecil, sedangkan hasil estimasi peningkatan genetik pertumbuhan yang dilakukan Susanto (1999) di uji keturunan sengon di Candiroto, Jawa Tengah umur 3 tahun menunjukkan peningkatan genetik diameter batang sebesar10,70\% dan tinggi pohon sebesar $9,54 \%$, namun bentuk batang mengalami penurunan genetik sebesar $1,10 \%$. Hasil studi peningakatan riap diameter batang Sengon di hutan rakyat oleh Riyanto (2009) menunjukkan bahwa penjarangan sengon secara fenotipik di hutan rakyat tidak mem-berikan peningkatan yang signifikan terhadap diameter batang. Nirsatmanto et al. (2012) juga telah meneliti efeisiensi seleksi pada $A$. mangium mulai umur 6 bulan sampai dengan 36 bulan. Setyaji dan Nirsatmanto (2009) melaporkan bahwa peningkatan genetik sengon umur 7 tahun adalah $-5,9 \%$ sampai dengan $20 \%$ untuk tinggi pohon dan $0 \%$ sampai dengan $15,5 \%$ untuk diameter batang. Heritabilitas individu bentuk batang yang lebih tinggi dibandingkan diameter dan tinggi pohon, maka menyebabkan peningkatan genetik bentuk batang di uji keturunan sengon di Cikampek cukup tinggi.

Uji keturunan Sengon di Cikampek materinya sama dengan uji keturunan sengon di Kediri, namun di Kediri uji keturunan tersebut terserang karat tumor (Baskorowati et al., 2012). Hal tersebut mengindikasikan bahwa lingkungan di Cikampek sangat menguntungkan terhadap tanaman sengon, keadaan tersebut diperlihatakan tidak adanya serangan karat tumor sama sekali pada uji keturunan tersebut. Cikampek mempunyai ketinggian 57 meter dari permukaan laut. Tanaman uji keturunan tersebut ditanam pada lahan bekas tanaman Acacia mangium, Khaya anthoteca dan Himenia aurbaril dengan jenis tanah Latosol kemerahan (Hadiyan, 2010). Kondisi lingkungan lokasi penelitian mempu-nyai suhu rata-rata tertinggi $31^{\circ} \mathrm{C}$ dan terendah $28^{\circ} \mathrm{C}$, dengan rata-rata curah hujan tahunan 1.111,05 $\mathrm{mm} / \mathrm{th}$; dengan rata-rata bulan kering 5,3 bulan dan bulan basah 5,3 bulan.

\section{KESIMPULAN DAN SARAN}

\section{A. Kesimpulan}

Hasil penelitian di uji keturunan sengon di Cikampek, Jawa Barat, dapat disimpulkan bahwa:

1. Keragaman pertumbuhan (diameter batang dan tinggi pohon) dan bentuk batang dipengaruhi oleh faktor genetik baik pada umur 2 tahun 
maupun umur 4 tahun (hal tersebut diperlihatkan pada analisis varian bahwa sumber variasi famili signifikan terhadap diameter batang, tinggi pohon dan bentuk batang).

2. Seleksi pohon akan meningkatkan perolehan genetik pertumbuhan dan bentuk batang sesuai dengan intensitas seleksi yang akan dilaksanakan, intensitas seleksi yang digunakan $(i=1,271)$.

3. Lingkungan Cikampek sangat menguntungkan terhadap tanaman sengon, karena tidak ada serangan karat tumor pada uji keturunan Sengon.

\section{B. Saran}

Untuk mempertahankan keragaman genetik pertumbuhan dan bentuk batang pada generasi berikutnya, maka dalam melakukan seleksi pohon disarankan memilih pohon terbaik di dalam plot, dengan cara seleksi kombinasi antara seleksi individu dengan seleksi famili.

\section{PERSANTUNAN}

Penulis mengucapkan terimakasih kepada Bp Burhan Ismail yang telah membangun uji keturunan Sengon di Cikampek; Bapak Ucup dari KHDTK Cikampek, dan Bapak Heri teknisi B2PBPTH Yogyakarta yang telah membantu dalam pengukuran dan pengamatan uji keturunan sengon di KHDTK Cikampek.

\section{DAFTAR PUSTAKA}

Balai Besar Penelitian dan Bioteknologi Tanaman Hutan. (2010). Penyiapan benih unggul untuk Gerakan Nasional Rehabilitasi Hutan dan Lahan.

Baskorowati, L., Susanto, M., \& Charomaini, M. 2012. Genetic variability inresistance of Falcataria moluccana to gall rust disease. Journal of Forestry Research Vo. 9. No.1, p: 1-9.

Broto, H. (2008). Model penduga volume sengon (Paraserianthes falcataria) pada tegakan hutan rakyat. Tidak diterbitkan. Skripsi. Departemen Manajemen Hutan. Fakultas Kehutanan. Institut Pertanian Bogor.

Charomaini, M. (1996). Evaluasi progeny Paraserianthes falcataria di Sumberjaya, Lampung Barat dan kemungkinan sebagai ras lahan. Buletin Penelitian Kehutanan Pematang Siantar 11(14), p: 399-409.
Dwiyanti, G.F. (2009). Keragaman sengon Solomon (Paraserianthes falcataria (L) Nielsen) pada uji keturunan di hutan percobaan Cirangsat. Skripsi. Departemen Silvikultur. Fakultas Kehutanan. IPB. (http: //repository. ipb.ac.id/ bitstream/handle/123456789/20727/E09fgd.p df? sequence=1)

Falconer, D.S., \& Mackay, T.F.C. (1996). Introduction to quantitative genetics. Longman. Edinburgh Gate, Harlow, England.

Hadiyan, Y. (2010). Pertumbuhan dan parameter genetik uji keturunan sengon (Falcataria moluccana) di Cikampek, Jawa Barat. Jurnal Pemuliaan Tanaman Hutan Vol.4 No. 2. p: 101108.

Hai, P.H. (2009). Genetic improvement of plantationgrowth Acacia auriculiformis for swan timber production. Unpublished Doctoral Thesis. Swedish University of Agricultural Sciences. Uppsala.

Ishiguri, F., Eizawa, J., Saito, Y., Iizuka, K., Yokota, S., Priadi, et al. (2008). Variation in the wood properties of Paraseriathes falcataria planted in Indonesia. IAWA Journal Vol.28 (3), p:339348.

Krisnawati, H., Varis, E., Kallio, M., \& Kanninen, M. (2011). Paraserianthes falcataria (L.) Nielsen. Ekologi, Silvikultur dan Produktivitas. Bogor: Center for International Forestry Research.

MacDonald, E., Mochan, S., \& Connoly, T. (2014). Validation of a stem straightness scoring system for Sitka spruce (Picea sitchensis (Bong.) Carr.). Forestry an International Journal of Forest Research Vol 82, pp 419-429.

Mukmin, A. (2004). Uji keturunan saudara tiri (Halfsib) sengon (Paraserianthes falcataria $\mathrm{L}$. Nielsen) di Taman Hutan Blok Cikabayan. Skripsi. Departemen Silvikultur. Fakultas Kehutanan. IPB. http: //repository.ipb.ac.id /bitstream/handle/123456789/20593/ E04AMU.pdf? sequence=1.

Muslimin, I., Sofyan, A., \& Islam, S. (2013). Parameter genetik pada uji klon jati umur 5,5 tahun di Sumatera Selatan. Jurnal Pemuliaan Tanaman Hutan Vol.7. No.2, p: 97-106.

Nisrsatmanto, A., Kurinobu, S., \& Shiraishi, S. (2012). Evaluation for the efficiency of early selection in Acacia mangium seedling seed orchards based on age trends in gnetic parameter. Journal of Forestry Research. Vol. 9. No.1, p: 16-24.

Olivia, R.D., \& Siregar, U.J. 2012. Keragaman genetik populasi Sengon (Paraserianthes falcataria (L) Nielsen) pada Hutan Rakyat di Jawa berdasarkan penanda RAPD. Jurnal Silvikultur Tropika. Vol. 03 No. 02, p: 130-136. 
Payne, R.W., Lane, P.W., Ainsley, A.E., Bicknell, K.E., Digby, P.G.N., Harding, S.A., et al. (1987). GENSTAT 5 Reference Manual. Clarendon: Oxford.

Pinyopusarerk, K., Kalinganire, A., Williams, E.R., \& Aken, K.M. (2004). Evaluation of International Provenance trials of Casuarina equisetifolia. ACIAR Technical Reports No. 58e. Canberra Australia.

Setiadi, D., Widyatmoko, A.Y.P.B.C., \& Fauzi, M.A. (2009). Uji Keturunan Araucaria cunninghamii di Sumberwringin, Bondowoso, Jawa Timur. Prosiding Espose hasil-hasil Penelitian Balai Besar Penelitian Bioteknologi dan Pemuliaan Tanaman Hutan 1 Oktober 2009. Status Terkini Penelitian Pemuliaan Tanaman Hutan. Hal:105-115.

Setiadi, D., \& Susanto, M. (2012). Variasi genetik pada kombinasi uji provenans dan uji keturunan Araucaria cunninghamii di Bondowoso, Jawa Timur. Jurnal Pemuliaan Tanaman Hutan Vol.6. No.3, p: 157-165.

Setyaji, T., \& Nirsatmanto, A. (2009). Uji perolehan genetik terhadap hasil pemuliaan generasi pertama jenis Acacia mangium pada umur 7 tahun di Jawa Tengah. Prosiding Espose hasil-hasil Penelitian Balai Besar Penelitian Bioteknologi dan Pemuliaan Tanaman Hutan 1 Oktober 2009. Status Terkini Penelitian Pemuliaan Tanaman Hutan. Hal:158-166.

Riyanto, H.D. (2009). Penjarangan selektif dalam upaya peningkatan riap diameter hutan rakyat sengon. Tekno Hutan Tanaman. Vol. 2. No.3, $\mathrm{p}: 115-120$.

Shelbourne, C.J.A. (1992). Genetic gain from different kinds of breeding population and seed or plant production population. IUFRO paper in Symposium "Intensive Forestry: The Role of Eucalyptus" held in Durban, South Africa, in September 1991.

Siregar, U.J., Siregar, I.Z., \& Sagita, H. (2002). Genetic variation of sengon (Paraserianthes falcataria), an important tree species for agroforestry, in West Java. Forest Management 163

Siregar, Z. S., Yunanto, T., \& Ratnasari, J. (2009). Kayu sengon, prospek bisnis, budidaya, panen dan pasca panen. 84pp. Jakarta: Penebar Swadaya.

Soerianegara, I., \& Lemmens, R.H.M.J. (eds). (1993). Plant Resources of South East Asia No. 5 (1). Timber trees: major commercial timbers. Wageningen. Netherlands: Pudoc Scientific Publishers.

Susanto, M. (1997). Evaluasi awal kebun benih uji keturunan jenis Paraserianthes falcataria umur 4 bulan di Candiroto Jawa Tengah. Buletin Penelitian Pemuliaan Pohon Vol. 2. No. 1 .

Susanto, M. (1999). Analisis parameter genetik kebun benih uji keturunan Paraserianthes falcataria umur 3 Tahun di Candiroto Jawa Tengah. Buletin Penelitian Pemuliaan Pohon Vol. 3. No. 1.

Susanto, M., Naiem, M., Hardiyanto, E.B., \& Prayitno, T.A. 2012. Analisa parameter genetik sifat kayu kombinasi uji provenan dan uji keturunan Acacia mangium di Kalimantan Selatan. Jurnal Pemuliaan Tanaman Hutan Vol.6. No.3. Hal : 131-142.

Susanto, M., Naiem, M., Hardiyanto, E.B., \& Prayitno, T.A. (2013). Variasi genetik sifat kayu uji keturunan Acacia mangium umur 5 tahun di Wonogiri, Jawa Tengah. Jurnal Manusia dan Lingkungan. Vol. 20 No. 3, Hal: 312-323.

Williams, E.R., \& Matheson, A.C. (1994). Design and analysis of trials for use in tree improvement. CSIRO, Melbourne.

Williams, E.R., Matheson, A.C., \& Hardwood, C.E. (2002). Experimental design and analysis for use in tree improvement. CSIRO, Melbourne.

Yudohartono, T.P., \& Ismail, B. (2012). Variasi genetik uji provenan merbau sampai umur 3 tahun di Bondowoso, Jawa Timur. Jurnal Pemuliaan Tanaman Hutan Vol. 6. No.1, Hal : 27-36. 